Article

\title{
Ecomuseums (on Clean Energy), Cycle Tourism and Civic Crowdfunding: A New Match for Sustainability?
}

\author{
Francesca Simeoni * (D) and Veronica De Crescenzo \\ Department of Business Administration, University of Verona, 37129 Verona, Italy; \\ veronica.decrescenzo@univr.it \\ * Correspondence: francesca.simeoni@univr.it; Tel.: +39-04-5802-8160
}

Received: 24 February 2018; Accepted: 12 March 2018; Published: 15 March 2018

\begin{abstract}
An ecomuseum is an 'instrument' to share the interests of a region and protect its cultural, historical and natural heritage. Cycle tourism is a sustainable type of tourism. Civic crowdfunding is a method of raising funds from a community for the fulfilment of civic initiatives. Starting from the literature on the link between cycle tourism and sustainability, the interaction between renewable energy resources and tourism, and finally the place-based dimension of a civic crowdfunding campaign, the purpose of this study is to show that an ecomuseum focused on clean energy has the potential to attract cycle tourists, increase the numbers of funders, as well as attract the interest of the municipality, not-for-profit associations and energy and tourism firms, and thus significantly enhance its beneficial effects on sustainability from economic, social and environmental points of view. This study employed an action research method to gain in-depth knowledge of this issue, as well as a qualitative case study approach to present and discuss the results. The principal result of this study is the identification of a potential way to create sustainability, via the match between an ecomuseum devoted to clean energy, cycle tourism and civic crowdfunding.
\end{abstract}

Keywords: ecomuseum; cycle tourism; civic crowdfunding; clean energy; sustainability

\section{Introduction}

Following the definition of the European Network of Ecomuseums, an ecomuseum is 'a dynamic way in which communities preserve, interpret, and manage their heritage for sustainable development' [1] (p. 85). Ecomuseums are entities 'uniquely positioned to foster creative change and adaptation aimed at sustainability' [2] that link local inhabitants and visitors to their environment [3,4], and are special museums composed of the sites, landscapes, memories of people, nature, traditions and heritage of each local community [5] (p. 41). To summarize, an ecomuseum is an harmonious union among museum activities, participation of the local inhabitants and the preservation of cultural and natural regional heritage. Ecomuseums are cultural institutions for advancing goals on sustainability [2]. Thus, ecomuseums are instruments to share the interests and protect the cultural, historical and natural heritage of a region. On this basis, ecomuseums could potentially link with the motivations for, and purposes of, cycle tourism, because both ecomuseums and cycle tourism actively consider the conservation of natural areas and common property. In fact, cycle tourism is considered an environmentally sustainable form of tourism with a minimal impact on natural areas and one which uses existing, under-used or disused facilities, such as canal towpaths or railway lines [6].

From the point of view of sustainability, it is important to develop cycle tourism because it encourages local trade and creates business opportunities [7]. It is also an environmentally sustainable form of tourism, thanks to the preservation of territory through the use of existing or under-used 
facilities, and in some cases even disused ones, such as closed railways, abandoned rural routes and neglected canal towpaths.

Various public and private organisations involved in the development of cycling periodically publish reports on what is necessary for the development of cycle mobility, and in particular, of cycle tourism. In this research study we have considered the Italian Federation of Friends of the Bicycle (FIAB; Federazione Italiana Amici della Bicicletta onlus), Sustrans in the United Kingdom (UK) and certain specific European Union commissions that work for the protection and promotion of cycle mobility. These reports highlight that it is necessary to:

- invest in safe, convenient and attractive cycle routes that cater for both long and short distance cycling;

- $\quad$ create safer and easier access points into and out of cities and towns;

- $\quad$ in general, develop a system of cycle routes away from vehicular traffic [7].

What is clear from these reports, and as we will show, is that cycle tourism is a sustainable form of tourism from the social, economic and environmental points of view. This tourism, as much as all nature-based tourism, is characterised by very different businesses. The success of these organisations derives from their internal factors. However, certain external factors, primarily lack of capital and problems with infrastructure, represent grave constraints [8]. Consequently, for nature-based projects such as some specific ecomuseums based on the integration between nature and culture, it is necessary to find the capital to finance these projects.

Civic crowdfunding is an alternative way of accumulating capital for projects that aim to improve peoples' wellbeing in total or partial substitution for public sector funding. Usually civic crowdfunding is used to finance public goods. In the context of the ever-increasing budget constraints in the public sector, civic crowdfunding can be an alternative mechanism for supporting public finance. In addition, civic crowdfunding is one of the tools for developing a new way for citizens to interact with the public sector; indeed, it represents a way to respond to citizens' increasing need for participation in public life [9].

Understanding of the potential role of civic crowdfunding requires an awareness of the place-based dimensions of this phenomenon. Civic crowdfunding is based on a strong sense of belonging and strong affective relationships to the region, and for this reason it is suitable for supporting placed-based projects, which are mainly local projects of public interest with social, cultural and environmental value [10] (p. 5).

This is the case with the emerging 'Ecomuseum of Clean Energy', a project that aims to create a new cycle path in the city of Verona, Italy, to enable the discovery of the cultural and historical renewable energy heritage of this city. The cycle route is an energy-efficient route, and it explores the heritage of energy production. The promotion of the hydroelectric history of the city of Verona is the resulting value of this project from a cultural point of view and the protection of the environment of the land alongside the canal system is the resulting value from an environmental point of view. Furthermore, the protection and promotion of this heritage by the Ecomuseum of Clean Energy may have an important effect on tourism. Indeed, the interaction between tourism and renewable energy sources (RES) has been demonstrated, and it is evident that RES have a strong impact on the tourism industry as a result of the eco-image of the destination, which increases the tourist flow [11].

Beer et al. [11] proposed a categorisation of the common interactions between RES and tourism and demonstrated that as the level of interaction progressively increases, the number of visitors grows, and their enthusiasm and interest encourages different potential stakeholders to invest in the project. Our starting point consists of the connection between cycle tourism and the ecomuseum based on RES. In this context, we will test if this connection is able to guarantee a growing number of visitors, and, at the same time, to increase the interest of the municipalities and energy companies in investing in the project. Starting from what has been demonstrated with regard to the link between cycle 
tourism and sustainability and the interaction between RES and tourism, the research aims to address three questions:

- (Q1) can an ecomuseum focused on RES culture and heritage that can be enjoyed by cycle tourists increase favourable effects on sustainability?

- $\quad(\mathrm{Q} 2)$ can such an ecomuseum attract more cycle tourists in this way?

- (Q3) and consequently, can it increase the interest of the community to invest in similar sustainable projects through a civic crowdfunding campaign, thanks to the growing interest in this area by municipalities, energy and tourism companies?

Referring to Kopnina [12], who has shown that 'there is the right way to be sustainable' (p. 27), this research aims to identify the 'right' way to sustainability, finding it in the match between an ecomuseum focused on clean energy, cycle tourism and civic crowdfunding.

The study employed an action research method to gain in-depth knowledge of these questions, and in this article, after a review of the literature on the concept of the ecomuseum, the cycle tourism phenomenon and the role of civic crowdfunding, we have employed a qualitative case study approach to analyse our findings. Next, the principal results are presented, and this paper closes with a discussion of the implications and the limits of this research.

\section{Literature Review}

\subsection{Overview of the Ecomuseum Concept}

The ecomuseum is a worldwide phenomenon. It has been estimated that there are at least 400 ecomuseums worldwide [13]. The origins of the ecomuseum date back to the 1970s and have been ascribed to two authors: Georges-Henri Riviére and Hugues de Varine. Georges-Henri Riviére first focused the concept on both ecology and the environment, then added the role of society to complete the idea of the ecomuseum. Ten years after his first definition, he provided a list of points that better explained the concept of the ecomuseum [4], concluding that it reflects the underlying relationship between humanity and nature [3].

Hugues de Varine was the originator of the prefix 'eco' in the term "ecomuseum", which is intended to be a balanced system between society and the environment, with the idea that people are responsible for protecting and using the environment and its natural resources [14].

Now, the ecomuseum is considered as an instrument to share the interests of, and protect the cultural, historical and natural heritage of, a region. The elements that identify an ecomuseum are the museum activities, the participation of the region's residents, and the preservation of regional heritage [5]. The results of the union of these elements may be different in each situation, and they also depend on local circumstances [15] and on the regional sociological and cultural conditions [16]. In this sense Ecomuseums are a malleable concept that tries to give an answer to contexts that are unique by covering spatial and temporal aspects [1]. The situation is different when this label is used as a marketing tool, without representing the original characteristics of an ecomuseum [17]. Often, so-called ecomuseums only present the connection between meaningful places and local resources and, as a consequence, they lack museum activity [5]. When the ecomuseum label is used mostly as a marketing tool, for example, for open-air history museums, there is often little or no attention given to fostering sustainability or addressing the current cultural realities associated with it.

The connection between cultural and natural heritage is consistent with the demands of the tourist market. Tourist operators see cultural tourism as an important way of developing their markets at the global level [18]. Cultural offerings in regions of natural appeal, with impressive landscapes, important historical and geological aspects and sightseeing opportunities have the potential to attract more visitors, engage local communities, and motivate the protection and conservation of the local heritage $[8,19]$.

In this sense, the ecomuseum can be seen as a sustainable development [1] and as an attractive prospect for investment in responsible tourism [20]. For instance, this is the case for the Ecomuseum 
of the Ibar Valley, where the development of the cultural and environmental resources of the region function as guidelines for the development of sustainable tourism [19]. Similar cases can be found in China, where the cultural heritage that they hope to preserve is that of the indigenous cultures of their ethnic minorities. Ecotourism in China is no longer limited to these cases, but the model is successfully moving from the national minority agricultural zones to urban, industrial and prosperous farming areas [3], as these territories are increasingly seen as having a cultural and natural heritage worth protecting through sustainable tourism.

In a different example from the United States, the Ak-Chin Indian Reservation, it is possible to highlight a new aspect of the mission of an ecomuseum: the protection of human dignity and the link between generations in the interest of the staff members, community members and also non-community members [21].

Some other and interesting examples can be found in France, Mexico, Germany, the Netherlands and the UK [22]. Two examples from Italy are the Ecomuseo Adda di Leonardo, in the province of Milan, and the Ecomuseo Urbano Metropolitano Milano Nord. The first opened in 2004, and focuses on the history of Leonardo da Vinci as cultural heritage, and traversing the Adda River as the natural heritage to be protected. This case is important because it represents the first example of the public funding of such a project, in the form of an agreement between the Ministry of the Environment and the Region of Lombardia. The second ecomuseum was created in 2007, and resulted from the idea of a group of researchers who wanted to protect the memory of a piece of Milan's history from the Second World War and the renaissance of the region after the war, then the subsequent changes in the use of this territory by the industry, leaving the region as it is today. This case is important because of the successful use of a new tool (crowdfunding) to finance certain of the activities of the ecomuseum, and the opportunity to visit the park by bicycle [23]; both aspects of interest in this study.

These cases illustrate the variety in the types of ecomuseums, their different characteristics and funding mechanisms. However, the constant is that all ecomuseums offer an open environment, where inhabitants are encouraged to take control of their own future based on their past. It means that an ecomuseum should create, for a community, a unique pride of place where people want to live or visit, and have an interest to invest [2].

What remains to be discussed is the question of governance, strategy and leadership. Ecomuseums seem to have the capacity to create new forms of partnership between the public, private and/or third-party sectors via a quicker process, thanks to their bottom-up approach, the likelihood of professionally led partnerships of unquestionably high quality, and the chance to establish a long-term legacy [22]. Consequently, the measures used to evaluate ecomuseums are necessarily different to those used for more traditional museums, and an evaluation instrument that highlights the philosophy of these ecomuseums and their role in local development and regeneration is needed. Such tools must be able to assess facets of ecomuseum activity, such as the creation of new knowledge, experiences, and the new skills acquired by the community, as well as the capacity to create a complex network of different members with the final purpose of enhancing the enjoyment of the territory for all [24], with a satisfying degree of community participation [25].

\subsection{Evidence from the Cycle Tourism Literature}

Currently, interest in cycling is growing due to the relationship between the lack of physical activity and the risk factors for global mortality, as announced by the World Health Organization. Many studies have investigated different aspects of cycling within the wider concept of active transportation [26].

Beyond this increasing recent interest, the specific relationship between cycling and tourism as a research topic began in the 1890s [27]. Since then, many definitions have been proposed for cycle tourism, but in general they are not clear or consistent. From a technical point of view, it is possible to state that bicycle tourism is a form of tourism that moves individuals from their home region to another one [28]. The purpose of this form of tourism may be either active or passive participation in 
cycling, meaning that the trip could be both for attendance at commercial or charity events or to cycle in an independently organised tour. Consequently, the possible motivations for cycle tourism may be for holidays, recreation, leisure or competition. Nevertheless, a certain confusion remains between the different studies regarding the separation or pooling of same-day excursionists and overnight visitors when cycle tourism is to be measured for reporting rigorous and consistent statistical results.

A great deal of attention has been given to analysis of suitable infrastructure, and in particular the different type of cycle paths and cycling facilities. What emerges from this literature is that there is no unique solution suitable for all cities and nations [29], although some general indications are evident.

As Deenihan and Caulfield [7] stated, cycle tourists value different levels of cycling infrastructure. For example, a study of cycle tourists in Dublin revealed that a cycling facility that is fully segregated from other traffic can increase the time dedicated to cycle tourism by $100 \%$, while providing a cycle lane beside a road can increase cycling time by $40-50 \%$. Moreover, this study demonstrated that tourists were willing to pay $48 \%$ more for cycling in cycle lanes rather than on a road without a dedicated bicycle lane, while this rose to $98 \%$ for cycling facilities that were fully segregated from traffic. These authors, estimating a value of time of 27.81 euro an hour, demonstrated that 'a cyclist is willing to pay 0.22 euro per minute for a road with a cycle lane and 0.45 euro per min for a fully segregated from traffic cycling facility' [7] (p. 100).

Furthermore, it is not only the type of cycle lane that affects the potential for increasing the number of cyclists, but also factors including cycle parking facilities at employment locations and cycle training and education activities [30]. An example of this comes from Portland, Oregon, where an increase of $210 \%$ in cycling has been registered, along with a significant correlation with improvements in the city's cycle network after an investment in cycling infrastructure over a period of 13 years [31]. Thanks to research in New Zealand [32], a list of investments useful for any country is available (see below). As Ritchie took a demand-side perspective to understand the real needs of cycle tourists and which infrastructure was worth investing in to ensure a sustainable future, this and other research has highlighted the importance of consulting active cyclists 'to incorporate users' site-specific knowledge into bicycle infrastructure assessments' [33] (p. 1).

In addition, cycle tourists consider the attributes of the tourism product to be very important. In particular, they value sightseeing along cycle routes and 'excellent sources of nature (beautiful landscape, various topography, etc.); man-made resources (characteristic architecture, historic sites, heritage, etc.); and comfortable weather' [34] (p. 99). From what they perceived their loyalty to the tourism product increases as much as their satisfaction and their willingness to pay.

Other authors have sought to understand the economic impact of cycling. Beyond the potential economic savings in terms of public health [35], other factors specifically influence the economic results, particularly for cycle tourism. For instance, Downward, Lumsdon and Weston [36] found that the level of the expenditure by cyclists depends on their incomes, the group size and the duration of their activities, and that the level of expenditure was the same even for those who were not cycling as authentic tourists, but were local people who valued a similar experience to those they had enjoyed while on holiday elsewhere.

In conclusion, cycle tourism seems to be a very important form of sustainable development for a region. For example, Australia has identified an important niche market for cycle tourism [37], while Verona in Italy has reached the same conclusion. However, it is necessary to conduct strategic planning to improve and guarantee the safety of the infrastructure available and to increase the amenities for cycle tourists. A positive answer may be investment in the Ecomuseum of Clean Energy, starting with development of a new cycle path in the city of Verona and the provision of a range of different services suitable for both tourists and the local inhabitants. 


\subsection{The Roles of the Community and the Public Sector: Key Dimensions for the Fulfilment of a Civic Crowdfunding Round}

Crowdfunding is a way of collecting funds from the crowd to finance specific projects, usually through a Web platform [38] (p. 3). In the broad framework of crowdfunding, civic crowdfunding is a method of raising funds from a community of people for the fulfilment of civic initiatives in total or partial substitution for funding by the public sector.

Three important elements must be considered to evaluate the potential use of civic crowdfunding: the type of initiative to be funded, the community's role and the public sector's engagement in the funding round. The initiatives for which funds are raised by a civic round must be useful for the entire community. To be considered civic the initiative must pursue a goal of public interest and must be aimed at improving the community's wellbeing. Undoubtedly, the possible objects of civic crowdfunding are pure public goods, characterised by non-excludable and non-rival use, consumption and enjoyment [39] (p. 2). Civic crowdfunding objects may also be a 'club good' (i.e., excludable but non-rival) or 'common good' (i.e., non-excludable but rival) if the initiative directly or indirectly generates a benefit for the whole community [40] (p. 343). It has also been observed that the typical goal for civic fundraising campaigns is local public goods, or public goods that benefit only the geographical community where they are located [10] (p. 5). Usually the initiatives funded by civic crowdfunding campaigns are mainly projects of public interest with social, cultural and environmental value. Smaller initiatives, according to the amount of funds required, tend to prevail, even if, in theory, initiatives of any size should be financed [41] (pp. 57-58).

The definition of civic cannot be considered a precise definition, and consequently it is not possible to list all the types of initiatives (goods or services) that have the potential to be funded by civic crowdfunding campaigns. Regardless, these different initiatives can all be defined as place-based projects, since civic crowdfunding relies on a particular type of crowd; that is, the community. In this context the platform plays the role of a catalyst for the off-line community whose people share a common interest in the crowdfunded project [10] (p. 5).

For civic crowdfunding the concept of community is fundamental. The connection between the project to be funded and the community of funders may transcend the purely spatial dimension. Geographical communities consist of people belonging to the community because of geographical proximity; while relational communities consist of people belonging to the community because of a special interest in a specific project [42] (p. 8). People belonging to a community have some common features: they pursue the same aims; they usually feel a strong sense of belonging to their community based on past common experiences and history, and are aware of the importance of membership of their community $[43,44]$. Civic crowdfunding can attract a geographically proximate community, people that enjoy the benefits of a project (individual self-interest), but also a non-geographically proximate community, people motivated by a broader interest in financing a good or service despite not having the opportunity to enjoy the benefits directly for reasons of geographical location (self-and-others interest) [9] (p. 261). It has been demonstrated that the success of crowdfunding efforts is influenced by the communities to which they belong and that the community's interest in the project is driven by the match between the potential benefit of the project and the cultural value of its target community [45] (pp. 176-177).

These features are fundamental to understanding the link between the community and the fulfilment of a civic crowdfunding round; indeed, they are the key elements that foster a community's capacity to implement and sustain collective action to achieve common objectives (civic capacity) [46] (p. 13). People who act for the social and cultural development of an area must be considered the most motivated funders of a civic crowdfunding round. In this context, civic crowdfunding is also a way to foster the development of smart cities, and more generally social innovation, as community-based initiatives require engagement from local citizens [47] (p. 314) [48] (p. 2).

Another specific feature of a civic fundraising campaign is the shortage of public funds (collected through general taxation) to realise the desired initiatives [49] (p. 4). As a result of the place-based 
dimension of these initiatives, the public body involved is usually a local government (or more than one if the initiative is located in a wide area).

The public body may or may not be given an active role as a selector or proponent and as a co-funder of the initiative. Other initiatives' proponents might be civil society organizations or citizens. The degree of involvement of public bodies in defining the crowdfunding campaign and in contributing financially to it represents another fundamental feature to understanding the potential of this new fundraising channel. If the proponent of a fundraising campaign is the public sector, without active participation from citizens, non-profit associations and firms, the crowdfunding campaign is defined as a public initiative [49] (p. 4).

Where the choice by the public sector to act as a co-funder is concerned, it is interesting to underline the possible different timings of this choice and their related meanings. Differences in timing in the co-funding process imply different roles for the public body. Two options are available: co-funding before (ex ante) or after (ex post) the crowdfunding campaign. Ex ante co-funding signals a strong commitment by the public body and implicitly also the potential value of the initiative. One risk exists: the public body must determine the amount it means to invest before knowing the success rate of the crowdfunding campaign. In the case of ex post co-funding, the public body assumes the role of residual funder. The aim is to ensure the successful conclusion of a funding round and the size of the contribution depends on the success rate of the fundraising campaign. It is normal to express the size of the public body's contribution as a percentage of the total amount required for the project to be fully funded.

\section{Methodology}

In order to gain in-depth knowledge of this subject, an action research method characterised by collaboration between the researchers and members of organisations was employed [50]. With this approach, there is an initial phase of diagnosis of the problem, followed by a phase of acting and developing a solution with continuous reflection on the processes and results. All these phases can cyclically repeat. A researcher using this method is required 'to initiate and support involvement of self and others in action as well as (have) the capability to reflect critically on the process and outcomes of the action engagement' [51] (p. 220). While this is the guiding principle of action research, it is not the only method. For this research study we used a community action research approach that 'forges research alliances with relevant stakeholders in the community to explore and develop solutions to local problems. (...) The ultimate goal is to develop sustainable community-based solutions' [52] (p. 123).

Following these guidelines, the researchers carried out action research in Verona, Italy, for the Ecomuseum of Clean Energy project. This project was selected because the three research aspectsprotection of the common property and natural areas, development of sustainable tourism and organisation of a complex management system - were all present simultaneously. Hence, this may represent an important benchmark case.

The researchers began this project two years ago and from that time they have: (1) made participative observations; (2) conducted fieldwork interviews; (3) collected first-hand information; (4) discussed the problems with the principal stakeholders; (5) presented the results to the community; and (6) given some lectures on this issue at both the undergraduate and postgraduate levels.

In particular, the following stakeholders were engaged regarding these different ways:

- The promoting and organising committee of the project; and in particular, but not only, the President of FIAB (2), (3) and (4);

- Experts from different fields, with whom the different possibilities and consequences of the project were discussed (2), (3) and (4). The principal people involved were: the director of another ecomuseum in Italy (Ecomuseo di Leonardo, Trezzo sull'Adda, Italy); a delegate from the FAI (Fondo Ambiente Italiano, Milan, Italy), an organisation dedicated to protecting and promoting the historic, artistic and landscape heritage of Italy; a delegate of the medical and prevention community; as well as several experts in the geography and history of the region; 
- The municipality and the principal economic and political stakeholders of the city of Verona, with whom the project was discussed, with the aim of having it included in the strategic plan for the destination management organisation of Verona (Piano strategico DMO Verona, 2017) (1), (2), (4) and (5);

- The project and its potential impacts were presented to the residents of the community involved during an ad hoc conference in the city in 2017 (5);

- Students (and their families) of a primary and secondary school, who developed many different sub-projects to improve the community impact of the Ecomuseum (2), (3) and (5);

- Approximately 400 undergraduate students as part of their Management for Tourism course (3) and (6);

- Approximately 50 postgraduate students as part of their advanced/professional development course in New Professions: Cycling Promotor (3) and (6).

All the data and information collected from the activities stated above were read and analysed first individually by the two researchers and then developed with a coding scheme by following an open approach [53].

In order to better understand this unique project, to present and discuss the results we have employed a qualitative case study approach. Several authors have encouraged qualitative methodologies for tourism research [54-56]. A single case study approach was employed [57]: the Ecomuseum of Clean Energy in Verona. Nevertheless, this case study may be considered an intrinsic case study [58] and consequently is not only representative of similar cases, but is interesting in its own right.

As Siggelkow [59] recommends, we have provided a description of the theories on ecomuseums and cycle tourism; we will now present the specific case study through a narrative of the case and testing of these theories. In this way, the case study will generate new ideas and suggestions and motivate new research questions.

\section{The Ecomuseum of Clean Energy Case Study Results: A Narrative from Action Research}

Starting from the existing knowledge, the basis of all ecomuseums is the idea that the owners of the natural and cultural heritage of a region have the responsibility to protect and develop it [3]. The owners are considered to be the primary stakeholders, and are represented by the citizens [14]; in other words, the crowd. Consequently, a bottom-up approach is both natural and necessary for the realisation and maintenance of the project and for a financial contribution.

The case analysed in this study is in the city of Verona, and involves the creation of a new cycle path and discovery trail incorporating the cultural and historical heritage of renewable energy in the city. The proposed project has multiple values: from a cultural perspective, the promotion of the hydroelectric history of the city of Verona; and from a natural perspective, the protection of the environment of the land alongside the canal system.

The new path should be of interest to Verona's citizens due to the improvement in sustainable urban mobility (cycle mobility), as well as to tourists, who will be able to cycle for $50 \mathrm{~km}$ through an area protecting a piece of Italian history and connecting with the principal cycle path from northern Europe and another path to southern Italy. These two different communities involved, the citizens and the cycle tourists, represent the target of the project, which should attract investment from both the public sector, such as the municipality, and the private sector, such as tourism operators.

The name of the ecomuseum is connected to the cultural and historical heritage that it aims to add value to. The new path will enable travel alongside a canal system connecting dams and hydroelectric plants. Hydropower is included in the list of the RES, together with biomass, geothermal, solar, wind and marine energies, and these renewables are considered the cleanest energy resources [60,61]. The fact that the path also passes a wind farm will aid development of the project more broadly as an ecomuseum of clean energy in general, not only of hydroelectric energy. 
The planned cycle path involves the protection of natural resources, thus fulfilling the aim of making these resources available to the city. It will also add value to the past identity and culture of the city and its industry and innovation in terms of energy use. The project's proponent, that is FIAB-Verona with its President who represents the civil society's link to the cycle community, is not able to determine a precise budget for this initial investment, the new cycle path. Similarly, the public body, in particular the municipality who will likely manage the project, has not yet determined this amount. The current estimate is approximately 5-10 million euro. Although this is a large range, this approximation is sufficient for our purposes. Next, the project plans to refurbish two hydroelectric plants: the Centrale Del Colombarolo, which will become the Educational Centre for Renewable Energies and the Centre for River Environment Documentation; and the Centrale di Sorio Vecchia, which will become the Museum of Hydroelectric Technology. For the first site, substantial intervention is required due to the poor state of the building, which has been closed since 1938. Repairs are likely to require the investment of at least one million euro. For the second plant, it will be sufficient to simply modify rooms and spaces to accommodate museum exhibits.

Some additional small projects may also arise from the ecomuseum, such as private-including small-businesses involved in the distribution of products and services for all end-users, both citizens and tourists. For example, it may be possible to develop a smart ecomuseum app to facilitate the enjoyment of the ecomuseum, such as that used in the Buremi Village ecomuseum in Korea [5]. In addition, it may be useful to create a unified geographic information system (GIS) database of cycle infrastructure [62] for this trail, which may be integrated at a national level. This may benefit bicycle users both for commuting to work and for leisure activities, also supporting the relationship between vacation and daily activities [63].

Considering the many sub-projects linked to this ecomuseum, from the largest (the cycle path) to the smallest (e.g., the app), it is clear that the project is very complex, and therefore needs different experts and also could include different sources of funding; for instance, crowdfunding. It is certain that it will take time to design and realise the project in a tangible sense. Time is necessary according to the multiple phases needed: starting from the definition of the structural interventions (primarily for the cycle route and for the refurbishment of the two hydroelectric plants), passing through the identification of the financial resources and ending with the fulfilment of the project.

Here, we refer to Liu and Lee's [25] development model, which proposes a strategy taking into consideration the problems associated with ecomuseums: 'establishing a public-private collaborating platform, initiating tourism community empowerment, and legally defining the cultural landscape' (p. 13265). The Ecomuseum of Clean Energy has passed the estimation stage (the first stage) and is now entering the preparation stage (the second stage). Specifically, the project has completed the first three tasks (the model lists 11 tasks in total):

1. Establishing complete context and region in which cultural and natural heritage is to be protected: The project has been completely described and contextualised and this shared information has been published in the 'Manifesto programmatico per l'ecomuseo dell'energia pulita', a document reviewed by the proponent of the project, FIAB-Verona.

2. Actively collecting local residents' opinions: The project has been presented to the local residents and opinions have been collected. Two of the major functions included a presentation at a dedicated conference in the city of Verona in March 2017, and a presentation, with subsequent collaboration, at schools in the area close to the proposed cycle path.

3. Starting the investigation and eliciting local knowledge: in the last two years, there have been many formal and informal meetings for the presentation and discussion of the project with the municipalities involved, their citizens, other public organisations and the owners of the land occupied by the path, as well as the University of Verona. 
It is now necessary to continue with the next tasks to collect new findings and evidence of the effects of this project on the local society, the environment and the economy, and to discuss these aspects further with the stakeholders.

\section{Discussion: A New Match for Sustainability?}

The ecomuseum is an instrument to share the interests and to protect the cultural, historical and natural heritage of a region. Cycle tourism is a sustainable form of tourism from the social, economic and environmental points of view. Civic crowdfunding is a new channel for raising funds to finance public goods or services of public interest that relies on peoples' sense of belonging and their affective links to a region and a community of people. The first question of this research (Q1) is to determine how an ecomuseum based on the RES and for cycle tourists has the necessary traits to enhance its favourable effects on sustainability from the economic, social and environmental points of view.

Cycle tourists value natural attractions and man-made resources with significant sightseeing potential along the route [34]. As in the case of the tide mills saved from destruction or total ruin along the European Atlantic littoral, for example the ecomuseum of Seixal in Portugal or the ecomuseum at la Coruña in Spain [64], these sightseeing resources are present in the case of the Ecomuseum of Clean Energy and add value to the project. Moreover, as in the case of the tide mills, which promote different businesses such as museums, dwellings, antique shops and restaurants, thanks to the Ecomuseum of Clean Energy it will be possible to create many different businesses, not only those related to the services provided for cycle mobility and cycle tourism, but also related to museum services themselves.

For instance, following Ritchie's proposal [32] and only considering the cycling aspect, there are a certain number of different businesses that could be created. From our analysis it is possible to expand this list, and as a result, generate an important economic impact (see Figure 1).

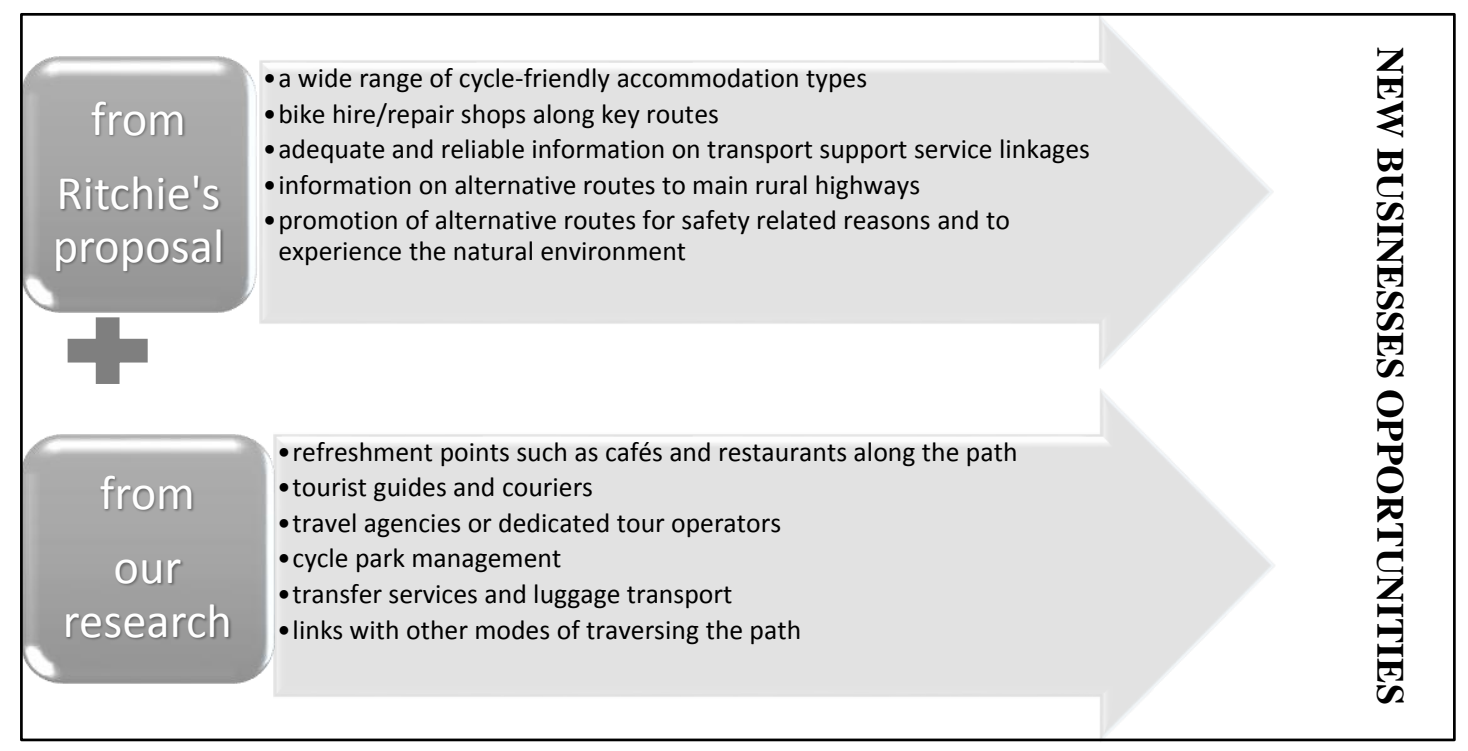

Figure 1. New businesses opportunities from an ecomuseum for the cycle tourists. Source: Our elaboration on Ritchie's proposal [32].

An ecomuseum could also include an important museum component, and therefore in this case the number and types of operators must increase to include all the possible companies and organisations that manage the museum aspect of the project. In our case, all that is necessary is to organise and open the museum and the educational centre and to promote special events linking the natural and cultural aspects of the project.

The output of these new businesses not only brings economic benefits to the organisations involved, but also provides a social contribution in terms of an improvement of the wellbeing of 
the local population. Indeed, by using the services provided, such as refreshment points, urban bike-sharing services and electric bicycle sharing [65], the local community can spend time with family and friends in a pleasant environment. This is a very important factor for human wellbeing and the sustainable development of a tourist area [66,67].

Finally, from an environmental point of view, there is an important link between an ecomuseum for cycle tourists if the ecomuseum is based on the RES culture and heritage.

Starting from Beer et al.'s [11] proposal, which demonstrated the interaction between tourism and RES, we test if it will be possible to achieve the greatest number of visitors in the case that the type of tourism involved is cycle tourism and the ecomuseum is based on RES. At the same time, we will try to understand if the increasing number of visitors has, as consequence, a greater level of interest in investing in the project by the municipalities and the energy companies. Figure 2 shows the proposed categorisation of Beer et al. [11] of the common interactions between RES and tourism. From the lowest to the highest levels of interaction, the number of visitors, and therefore motivation to invest in the project, increases.

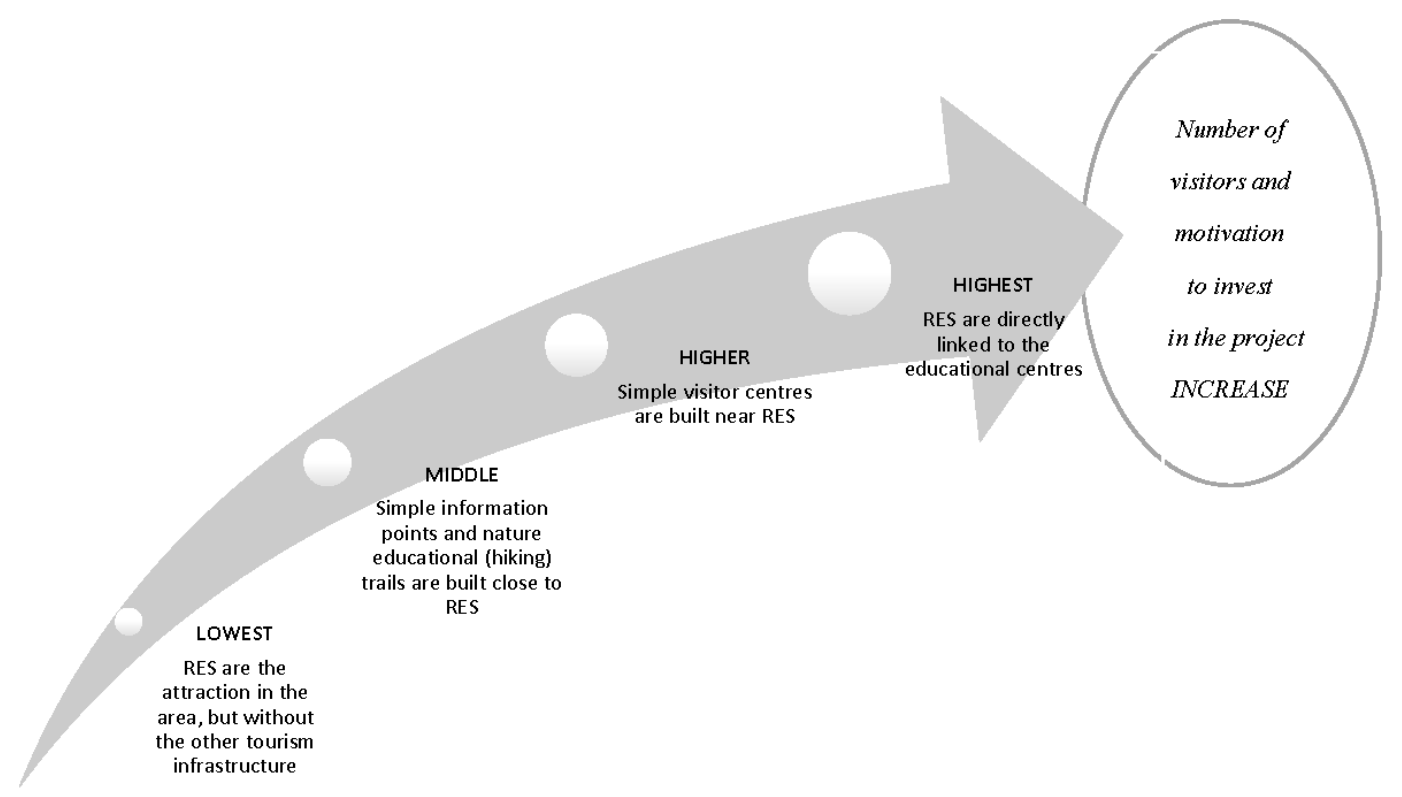

Figure 2. Relation and effects of the common interactions of renewable energy sources (RES) and tourism. Source: Our elaboration, from Beer et al. [11] (p. 5).

In the case of the Ecomuseum of Clean Energy, RES represent the cultural heritage on show for this region ('the attraction of the area' as in the lowest level of interaction), but the project is expected to generate many other various elements as illustrated at the middle level of this interaction. In fact, the ecomuseum project will provide information points or other simple services that facilitate access and enjoyment for tourists, as well as more complex elements, like the actual educational cycling trail close to the RES, which is the route of the ecomuseum. Nevertheless, the proposed project, including the Educational Centre for Renewable Energies and the Centre for River Environment Documentation plus the Museum of Hydroelectric Technology, may match the third level of this categorisation-the higher level.

Conversely, to reach the highest level of interaction it will be necessary to refurbish the two centres using a RES system and this is not an absolute certainty; achieving this will depend on the amount of investment achieved. Nevertheless, the fact that the route of this ecomuseum is feasible for cycle use may enable this tourist proposition to meet (or almost meet) the requirements of this fourth and highest category, inasmuch as cycle tourism has been shown as a significant type of sustainable tourism with a low environmental impact. 
Taken together, it is possible to answer the second question (Q2) that shows a match between cycle tourism and an ecomuseum only if the latter proposes its clean energy heritage as its cultural value, contributing to the achievement of the highest category of interaction of RES and tourism. This in turn leads to the best results in terms of a tourism attraction, as measured by an increased cycle tourist flow and the valorisation of the region's cultural, historical and natural heritage with the potential for greater community interest.

A community is composed not only of its citizens, but also of its not-for-profit associations and firms interested in the development of certain geographic areas. These different components of the interested community could potentially assemble a group of investors: individual citizens; civil society organisations (e.g., the FIAB); private businesses, including from the tourism and energy sectors; the relevant municipalities and the Ministry of Culture and Environment, among others. Matching funds from public bodies and other representative organisations might indicate a high-quality project, and may boost the confidence of potential private and single investors with regard to the project and, last but not least, can act as a tool to increase the probability that the project will be realised and speed up this process.

The composition of the group of funders and the contributions of the different types of funding (including public) are critical for the fulfilment of an ecomuseum project, but the presence of the community ('crowd') of people that has both the responsibility to protect and use the environment and its heritage and to take part in the process of funding these projects is the key element for boosting the potential of civic crowdfunding as an alternative way of fundraising. Thus, to answer the third question (Q3), for a bottom-up approach to the ecomuseum project and the crowdfunding instrument, we must start with the local community and increase the size of this 'crowd' to include the cycle tourist community.

\section{Conclusions}

Starting from what has already been demonstrated in terms of the links between cycle tourism and sustainability [7], the interaction between RES and tourism [11] and finally the placed-based dimension of a civic crowdfunding campaign [10], this research has shown that a proposed ecomuseum on clean energy has the potential to attract the highest level of cycle tourists, to increase the crowd of potential funders, thereby attracting the interest of the municipalities concerned, not-for profit associations and energy and tourism firms, and thus significantly increase the beneficial effects on sustainability from the economic, social and environmental points of view. The new knowledge, experience and skills created by such a project represents new and important benefits acquired by all stakeholders, which together create a complex local network with positive effects on society.

Local networks manage the planning, development and maintenance of these sites and contribute to the success of eco-cultural tourism [68]. Clearly, successful management and development of the ecomuseum beyond the planning stage is necessary to guide the long-term improvement of the project and allow the founder group to include the wider community in managing each of the objectives to be reached [1]. In any case, appropriate planning and presentation of the reasons for, and benefits of, the project may encourage the municipalities and energy and tourism companies involved to invest in it.

Italy receives approximately 450,000 cycle tourists each year [69], compared with more than 10 million in the whole of Europe, and therefore the potential of this form of tourism for Italy is very high. Further, if we consider that Deenihan and Caulfield [7] (p. 100) have estimated that a cyclist is willing to pay 0.45 euro per minute for cycling facilities that are fully separated from other traffic, and we assume an average speed of $20 \mathrm{~km}$ per hour, the Ecomuseum of Clean Energy path (50 km in total) is expected to generate 67.5 euro per cyclist. It is impractical to use this amount as justification for the project (a possible entry ticket value) because of the characteristics of the route (an open route in the region), but it is important to be aware of such figures to understand the values of the cyclists and therefore the scope of the businesses (products and services) that may need to be developed. 
An active community, consisting of a territorial community (the inhabitants of Verona) joined with a relational community (primarily cycle tourists), that effectively promotes the value of the ecomuseum responds to the need for a crowdfunding campaign to bring together as many people as possible and thus increases the probability of the success of the project. Thus, the crowd both pushes the project and contributes to its financing. On the basis of this conclusion, and from an academic point of view, it is possible to assert that this study contributes to understanding the use of this method of funding for an initiative such as an ecomuseum.

To our knowledge, this is the first study that has searched for a match that can create sustainability by including the ecomuseum phenomenon, tourism development and the instruments to finance such projects. An ecomuseum based on RES culture and heritage and enjoyed by cycle tourists may well attract interest from crowd funders considering investing in it, and thus bring to a new match to sustainability.

Moreover, many specific managerial implications can be derived from this research. For instance, if the museum and educational centres are refurbished using a RES system, the impact on tourist flow may further increase (reaching the highest level of interaction in Beer et al.'s [11] model). Therefore, certain suggestions can be proposed for the promotion phase of this project, such as promotion of the travel experience rather than the core products; an emphasis on the social inclusion of the locals along the route; and guarantees of the safety and appropriate size of the path, particularly for inexperienced tourists.

This research study on the Ecomuseum of Clean Energy may serve as a basis for future studies, the subjects of which also illustrate the limitations of this paper. First, at this stage of the project's development it is not possible to evaluate the results in terms of real cultural change. Nevertheless, considering that this is one of the aims of the Ecomuseum of Clean Energy, it would be interesting in future research to analyse the potential of the Ecomuseum to reach this goal. Natural experiments could be a proper research method in order to understand the opinions of the different types of stakeholders involved in the project and evaluate their cultural change. This new research is also important because the different cultural levels in the society represent one of the factors able to influence, de facto, the future energy needs of the city and, consequently, the sustainability of the whole project. Second, other empirical studies are needed for testing and confirming the conditions that in this case have shown to be necessary and sufficient in order to create such a sustainable model for the development of a territory and a community. Moreover, it is critically important to determine which type of bridging organisation could develop emerging ecomuseums and their associated services to improve the sustainability of these projects.

To conclude, the researchers are also aware of the fact that the literature on museums is not adequately considered, along with the literature on industrial and/or urban tourism, and these areas may offer new and interesting results.

Acknowledgments: There are no sources of funding for this study. No grants support our research, or publication in open access.

Author Contributions: Francesca Simeoni contributed to Sections 2.1, 2.2, 4 and 5, Veronica De Crescenzo contributed to Sections 1 and 2.3, while Francesca Simeoni and Veronica De Crescenzo contributed to Sections 3 and 6. All authors proofread and approved the final manuscript.

Conflicts of Interest: The authors declare no conflict of interest. There are no funding sponsors.

\section{References}

1. Davis, P. Ecomuseums: A Sense of Place, 2nd ed.; Continuum International Publishing Group: London, UK, 2011.

2. Sutter, G.C.; Sperlich, T.; Worts, D.; Rivard, R.; Teather, L. Fostering cultures of sustainability through community-engaged museums: The history and re-emergence of ecomuseums in Canada and the USA. Sustainability 2016, 8, 1310. [CrossRef]

3. Donghai, S. The concept of the ecomuseum and its practice in China. Mus. Int. 2008, 60, 29-39. [CrossRef]

4. Rivière, G.H. Ecomuseums: An evolutive definition. Mus. Int. 1985, 148, 182-183. [CrossRef] 
5. Bae, E.S.; Lee, S.Y. Smart ecomuseum app for efficient management of local resources. Int. J. Multimed. Ubiquitous Eng. 2014, 9, 41-50.

6. Sustrans. Cycle tourism; August 1999. 1999. Available online: http://www.sustrans.com/assets/files/Info\% 20sheets / ff28.pdf (accesses on 20 November 2012).

7. Deenihan, G.; Caulfield, B. Do tourists value different levels of cycling infrastructure? Tour. Manag. 2015, 46, 92-101. [CrossRef]

8. Lundberg, C.; Fredman, P. Success factors and constraints among nature-based tourism entrepreneurs. Curr. Issue Tour. 2012, 15, 649-671. [CrossRef]

9. Stiver, A.; Barroca, L.; Minocha, S.; Richards, M.; Roberts, D. Civic crowdfunding research: Challenges, opportunities, and future agenda. New Media Soc. 2015, 17, 249-271. [CrossRef]

10. Charbit, C.; Desmoulins, G. Civic Crowdfunding: A Collective Option for Local Public Good? Working Paper 2017/02; OECD Publishing: Paris, France, 2017; pp. 1-39.

11. Beer, M.; Rybár, R.; Kal'avský, M. Renewable energy sources as an attractive element of industrial tourism. Curr. Issues Tour. 2017. [CrossRef]

12. Kopnina, H. Sustainability: New strategic thinking for business. Environ. Dev. Sustain. 2017, 19, 27-43. [CrossRef]

13. Borrelli, N.; Davis, P. How culture shapes nature: Reflections on ecomuseum practices. Nat. Cult. 2012, 7, 31-47. [CrossRef]

14. De Varine, H. La Dynamique du Développement Local_Les Choix du Beaufortain; Editions Asdic: Paris, France, 2006.

15. Corsane, G.; Davis, P.; Elliott, S.; Maggi, M.; Murtas, D.; Rogers, S. Ecomuseum evaluation: Experiences in Piemonte and Liguria, Italy. Int. J. Herit. Stud. 2007, 13, 101-116. [CrossRef]

16. Maure, M. Ecomuseums: Mirror, window or tool for development? In Ecomuseums and Possible Lines of Development. Collected Works from the International Symposium on the Guizhou Ecomuseum; De Varine, H., Ed.; Zijin City Publishing House: Zijin County, China, 2006; p. 113.

17. Giménez-Cassina, E. Who am I? An identity crisis identity in the new museologies and the role of the museum professional. Cad. Sociomuseol. 2010, 37, 25-41.

18. Prentice, R. Heritage: A key sector of the 'new' tourism. In Progress in Tourism, Recreation and Hospitality Management; Cooper, C., Lockwood, A., Eds.; Wiley: Chichester, UK, 1994; Volume 5, pp. 309-324.

19. Terzić, A.; Bjeljac, Ž.; Jovičic, A.; Penjišević, I. Cutural Route and ecomuseum concepts as a synergy of nature, heritage and community oriented sustainable development. Eur. J. Sustain. Dev. 2014, 3, 1-16. [CrossRef]

20. Boylan, P. Ecomuseums and the new meseology—Some definitions. Mus. J. 1992, 92, 29-30.

21. Stokrocki, M. The ecomuseum preserves an artful way of life. Art Educ. 1996, 49, 35-43. [CrossRef]

22. Bowden, A.; Ciesielska, M. Ecomuseums as cross-sector partnership: Governance, strategy and leadership. Public Money Manag. 2016, 36, 23-30. [CrossRef]

23. Mascheroni, S.; Micoli, A. Ecomuseo Urbano Metropolitano Milano Nord: Towards a cultural biography of collective landscape. Riv. Ric. Per Progett. Paesaggio 2012, 1, 119-125.

24. Corsane, G.; Davis, P.; Elliott, S.; Maggi, M.; Murtas, D.; Rogers, S. Ecomuseum performance in Piemonte and Liguria, Italy: The significance of capital. Int. J. Herit. Stud. 2007, 13, 224-239. [CrossRef]

25. Liu, Z.-H.; Lee, Y.-J. A method for development of ecomuseums in Taiwan. Sustainability 2015, 7, 13249-13269. [CrossRef]

26. Wang, L.; Wen, C. The relationship between the neighborhood built environment and active transportation among adults: A systematic literature review. Urban Sci. 2017, 1, 29. [CrossRef]

27. Tobin, G. The bicycle boom of the 1890s: The development of the private transportation and the birth of the modern tourist. J. Pop. Cult. 1974, 8, 838-849. [CrossRef]

28. Lamont, M. Reinventing the wheel: A definitional discussion of bicycle tourism. J. Sport Tour. 2009, 14, 5-23. [CrossRef]

29. Alveano-Aguerrebere, I.; Javier Ayvar-Campos, F.; Farvid, M.; Lusk, A. Bicycle Facilities That Address Safety, Crime, and Economic Development: Perceptions from Morelia, Mexico. Int. J. Environ. Res. Public Health 2018, 15, 1. [CrossRef] [PubMed]

30. Stinson, M.; Bhat, C. An analysis of commuter bicyclist route choice using a stated preference survey. J. Transp. Res. Board 2003, 1301, 107-115. [CrossRef] 
31. Birk, M.; Geller, R. Bridging the gap: How the quality and quantity of connected bikeway network correlates with increasing bicycle use. In Proceedings of the 85th Annual Meeting of the Transportation Research Boards, Washington, DC, USA, 22-26 January 2006.

32. Ritchie, B.W. Bicycle tourism in the South Island of New Zealand: Planning and management issues. Tour. Manag. 1998, 19, 567-582. [CrossRef]

33. Boettege, B.; Hall, D.M.; Crawford, T. Assessing the bicycle network in St. Louis: A place-based user-centered approach. Sustainability 2017, 9, 241. [CrossRef]

34. Han, H.; Meng, B.; Kim, W. Bike-traveling as a Growing phenomenon: Role of attributes, value, satisfaction, desire, and gender in developing loyalty. Tour. Manag. 2017, 59, 91-103. [CrossRef]

35. Guariso, G.; Malvestiti, G. Assessing the value of systematic cycling in a polluted urban environment. Climate 2017, 5, 65. [CrossRef]

36. Downward, P.; Lumsdon, L.; Weston, R. Visitor expenditure: The case of cycle recreation and tourism. J. Sport Tour. 2009, 14, 25-42. [CrossRef]

37. Lamont, M.; Buultjens, J. Putting the brakes on: Impediments to the development of independent cycle tourism in Australia. Curr. Issue Tour. 2011, 14, 57-78. [CrossRef]

38. European Commission. Crowdfunding in the EU-Exploring the Added Value of Potential EU Action; Consultation Document; European Commission: Brussels, Belgium, 2013; pp. 1-12.

39. Hudik, M.; Chovanculiak, R. Private provision of public goods via crowdfunding. J. Inst. Econ. 2017, 38p. [CrossRef]

40. Davies, R. Three provocations for civic crowdfunding. Inf. Commun. Soc. 2015, 18, 342-355. [CrossRef]

41. Davies, R. Civic Crowdfunding: Participatory Communities, Entrepreneurs and the Political Economy of Place; Massachusetts Institute of Technology: Cambridge, MA, USA, 2014; pp. 1-173.

42. Mcmillan, D.W.; Chavis, D.M. Sense of community: A definition and theory. J. Community Psychol. 1986, 14, 6-23. [CrossRef]

43. Block, P. Community: The Structure of Belonging; Berrett-Koehler Publishers: San Francisco, CA, USA, 2008; pp. 1-228.

44. Mason, A. Community, Solidarity and Belonging: Levels of Community and Their Normative Significance; Cambridge University Press: Cambridge, UK, 2000; pp. 1-256.

45. Josefy, M.; Dean, T.J.; Albert, L.S.; Fitza, M.A. The Role of Community in Crowdfunding Success: Evidence on Cultural Attributes in Funding Campaigns to "Save the Local Theater". Entrepreneurship Theory Pract. 2017, 41, 161-182. [CrossRef]

46. Briggs de Souza, X. Democracy as Problem Solving: Civic Capacity in Communities across the Globe; MIT Press: Cambridge, MA, USA, 2008; pp. 1-26.

47. Bernardino, S.J.; Santos, J.F. Potential of civic crowdfunding to the intelligence of cities and social innovation: An exploratory study. In Proceedings of the Portuguese Association for Information Systems Conference, Porto, Portugal, 22-24 September 2016; pp. 311-323. Available online: http:/ / dx.doi.org/10.18803/capsi. v16.311-323 (accessed on 24 September 2017).

48. Carè, S.; Trotta, A.; Carè, R.; Rizzello, A. Crowdfunding for the development of smart cities. Bus. Horiz. 2017. [CrossRef]

49. Lee, C.H.; Zhao, J.L.; Hassna, G. Government-incentivized crowdfunding for one-belt, one-road enterprises: Design and research issues. Financ. Innov. 2016, 2, 1-14. [CrossRef]

50. Bryman, A.; Bell, E. Business Research Methods, 3rd ed.; Oxford University Press: Oxford, UK, 2011.

51. Levin, M.; Martin, A.W. The praxis of educating action researchers. Action Res. 2007, 5, 219-229. [CrossRef]

52. Ozanne, J.L.; Anderson, L. Community action research. J. Public Policy Mark. 2010, 29, 123-137. [CrossRef]

53. Corbin, J.; Strauss, A. Basics of Qualitative Research, 3rd ed.; SAGE: Thousand Oaks, CA, USA, 2008.

54. Pernecky, T.; Jamal, T. (Hermeneutic) phenomenology in tourism studies. Ann. Tour. Stud. 2010, 37, $1055-1075$. [CrossRef]

55. Riley, R.; Love, L. The state of qualitative tourism research. Ann. Tour. Res. 2000, 27, 164-187. [CrossRef]

56. Ryan, C. Ways of conceptualizing the tourist experience. A review of literature. Tour. Recreat. Res. 2010, 35, 37-46. [CrossRef]

57. Yin, R. Case Study Research: Design and Method; SAGE: London, UK, 2009.

58. Stake, R. Qualitative case study. In Handbook of Qualitative Research, 2nd ed.; Denzin, N., Lincoln, Y., Eds.; SAGE: Thousand Oaks, CA, USA, 2005; pp. 443-466. 
59. Siggelkow, N. Persuasion with case studies. Acad. Manag. J. 2007, 50, 20-24. [CrossRef]

60. Panwar, N.L.; Kaushik, S.C.; Kothari, S. Role of renewable energy sources in environmental protection: A review. Renew. Sustain. Energy Rev. 2011, 15, 1513-1524. [CrossRef]

61. Pang, R.-Z.; Deng, Z.-Q.; Hu, J.-L. Clean energy use and total-factor efficiencies: An international comparison. Renew. Sustain. Energy Rev. 2015, 52, 1158-1171. [CrossRef]

62. Bíl, M.; Bílová, M.; Kubeček, J. Unified GIS database on cycle tourism infrastructure. Tour. Manag. 2012, 33, 1554-1561. [CrossRef]

63. Brey, E.T.; Xinran, Y.L. The relationship between daily and vacation activities. Ann. Tour. Res. 2007, 34, 160-180. [CrossRef]

64. Charlier, R.H.; Menanteau, L. The saga of tide mills. Renew. Sustain. Energy Rev. 1997, 1, 171-207. [CrossRef]

65. Kaplan, S.; Manca, F.; Nielsen, T.A.; Prato, C.G. Intentions to use bike-sharing for holiday cycling: An application of the theory of planned behavior. Tour. Manag. 2015, 47, 34-46. [CrossRef]

66. Corral-Verdugo, V.; Frìas-Armenta, M. The sustainability of positive environments. Environ. Dev. Sustain. 2016, 18, 965-984. [CrossRef]

67. Mercado, L.; Lassoie, J. Assessing tourists' preferences for recreational and environmental management programs central to the sustainable development of a tourism area in the Dominican Republic. Environ. Dev. Sustain. 2002, 4, 253-278. [CrossRef]

68. Wallace, G.; Russell, A. Eco-cultural tourism as a means for the sustainable development of culturally marginal and environmentally sensitive regions. Tour. Stud. 2004, 4, 235-254. [CrossRef]

69. Babbi, A. Presentation to Convegno Euro Velo 8. In The Mediterranean Route-Best Practices, Inspiration and Networking in Cycling Tourism; ENIT: Mantova, Italy, 2015.

(C) 2018 by the authors. Licensee MDPI, Basel, Switzerland. This article is an open access article distributed under the terms and conditions of the Creative Commons Attribution (CC BY) license (http:/ / creativecommons.org/licenses/by/4.0/). 